\title{
DIAGENETIC PATTERN OF VERTEBRATE FOSSILS FROM THE TRAVERSODONTIDAE BIOZONE, SANTA MARIA FORMATION (TRIASSIC), SOUTHERN BRAZIL
}

\author{
MÍRIAM REICHEL, CESAR LEANDRO SCHULTZ \\ Depto. de Paleontologia e Estratigrafia, UFRGS, Av. Bento Gonçalves, 9500, 91509-900, Porto Alegre, RS, Brazil. \\ miriamreichel@yahoo.com.br, cesar.schultz@ufrgs.br \\ VITOR PAULO PEREIRA \\ Depto. de Mineralogia e Petrologia, UFRGS, Av. Bento Gonçalves, 9500, 91509-900, Porto Alegre, RS, Brazil. \\ vitor.pereira@ufrgs.br
}

\begin{abstract}
Two outcrops of the Traversodontidae Biozone, located in the municipal districts of Santa Cruz do Sul and Venâncio Aires, were analyzed for their diagenetic patterns. Both outcrops share a very similar faunal content, with a predominance of non-mammalian cynodonts, and also a common biostratinomic pattern. Macroscopically, the bones are characterized by the presence of a thin, dark coloured layer composed by manganese oxides, attached to the external surface and for the absence of volumetric distortions caused by diagenesis, which often occur in the fossils of the Santa Maria Formation. On the microscopic level, a poor osteological preservation is found. X-ray diffractometry and scanning electron microscopy analyses revealed a high percentage of quartz in the samples, unlike the fossil bones found in other locations and stratigraphic levels within the Santa Maria Formation, where only minimal concentrations of silica are found. The amount of quartz filling the bones reflects different paleoenvironmental conditions and is here also correlated to the volumetric changes in the bones at the different biozones within the Santa Maria Formation. In addition to the diagenetic patterns shared by the Santa Cruz do Sul and Venâncio Aires outcrops, their similar biostratinomy and faunas corroborate the hypothesis that both represent a distinct biozone within the Santa Maria Formation.
\end{abstract}

Key words: Bone diagenesis, cynodonts, faunal assemblage, silica, biozone.

\begin{abstract}
RESUMO - Dois afloramentos da Biozona de Traversodontidae, localizados nos municípios de Santa Cruz do Sul e Venâncio Aires, foram analisados em relação ao seu padrão diagenético. Os afloramentos apresentam um conteúdo faunístico muito semelhante, dominado pela presença de cinodontes não-mamalianos e, também, um padrão bioestratinômico comum a ambos, considerando suas tafocenoses. Macroscopicamente, os ossos são caracterizados pela presença de uma fina camada de coloração escura, composta de óxidos de manganês, na superfície externa, e pela quase ausência de deformações morfológicas (aumento de volume). Em nível microscópico, encontra-se uma pobre preservação osteológica. As difratometrias de raios-x e a microscopia eletrônica de varredura revelaram uma alta porcentagem de quartzo nas amostras, diferente dos fósseis encontrados em outras localidades da Formação Santa Maria, onde apenas concentrações mínimas são encontradas. A quantidade de quartzo preenchendo os ossos reflete diferentes condições paleoambientais e é aqui também relacionada às deformações volumétricas nos ossos de diferentes biozonas. O padrão diagenético similar dos afloramentos de Santa Cruz do Sul e Venâncio Aires, além de suas características bioestratinômicas e faunísticas semelhantes, corrobora a hipótese de que ambos representem um nível distinto na Formação Santa Maria, reforçando a presença de uma biozona distinta.
\end{abstract}

Palavras-chave: Diagênese óssea, cinodontes, associação faunística, sílica, biozona.

\section{INTRODUCTION}

Two outcrops of the Santa Maria Formation (MiddleUpper Triassic from southern Brazil), the "Schoenstatt" outcrop, located in the city of Santa Cruz do Sul and the "Vila
Estância Nova" outcrop, located in Venâncio Aires municipal district, have a fossil tetrapod assemblage of more than 90\% non-mammalian cynodonts. Among the over 50 specimens collected until now, the only occurrences not belonging to this group are a small archosaur (probably 
related to Rhadinosuchus, according to Machado \& Kischlat, 2003), found in Schoenstatt outcrop, and an indeterminate tusked dicynodont, found in Vila Estância Nova outcrop. This dominance of cynodonts does not occur in any other outcrop of the Santa Maria Formation. Besides, some cynodonts identified from the Schoenstatt outcrop, including Charruodon (Abdala \& Ribeiro, 2000) and Santacruzodon (Abdala \& Ribeiro, 2003), are distinct from those already described for the two biozones established for the Santa Maria Formation: the Therapsid Biozone (Mesotriassic) and the Rhynchosaur Biozone (Neotriassic) (Scherer et al, 1995; Schultz et al., 2000). Thus, Abdala et al. (2001), proposed a new biozone, the Traversodontidae Biozone, for the fossil assemblage found at that outcrop, which should be positioned between those cited above.

Lucas (2001) argued that the occurrence of the new fauna was much restricted (only at the Schoenstatt outcrop) and the new cynodont taxa do not represent a distinct stage of evolution related to those cynodonts from the underlying Therapsid Biozone (Dinodontosaurus Biozone of Lucas, 2001) to support the establishment of a distinct biozone, so that he included the Schoenstatt outcrop and its fauna in his Dinodontosaurus Biozone.

In this study, we analyze the diagenetic pattern of the fossil bones from the Traversodontid Biozone, including the Schoenstatt and Vila Estância Nova outcrops and also compare the data obtained from these two outcrops with those coming from other known outcrops belonging to the other biozones of the Santa Maria Formation. Our goal is to determine if, from a diagenetic point of view, the Schoenstatt and the Vila Estância Nova outcrops constitute a distinct level within the Middle-Upper Triassic sequence of Brazil.

\section{GEOLOGICAL SETTING AND LOCATION OF THE OUTCROPS}

The outcrops of Schoenstatt (Santa Cruz do Sul city, UTM 359767 E, 6709062 N) and Vila Estância Nova (Venâncio Aires city, UTM 394997 E, 6720253 N) (Figures 1 to 3) are composed of decimetric layers of massive red mudstones, alternated with amalgamated lenticular bodies of fine sandstones. These represent the typical association of the Alemoa Member of the Santa Maria Formation. The age attributed to this unit is Ladinian to Eonorian, based mainly on its paleotetrapods (Scherer et al., 2000).

The materials used for comparisons (Table 1) were collected in the Sanga Pinheiros outcrop, in Candelária city (UTM 331263 E, 6705014 N) and in the Faixa Nova outcrop, in Santa Maria city (UTM $229955 \mathrm{E}, 6711041 \mathrm{~N}$ ), in red mudstones and finegrained sandstones of Ladinian-Carnian age (Figure 1).

The Santa Maria Formation tetrapod fauna has been divided into two units: the Therapsid Biozone, of Ladinian age and the Rhynchosaur Biozone, of Carnian age (Schultz et al., 2000; Figure 4). The names indicate that the inferior zone is dominated by the presence of therapsid synapsids, especially the herbivorous dicynodont Dinodontosaurus, while the hyperodapedontid rhynchosaurs (Diapsida,

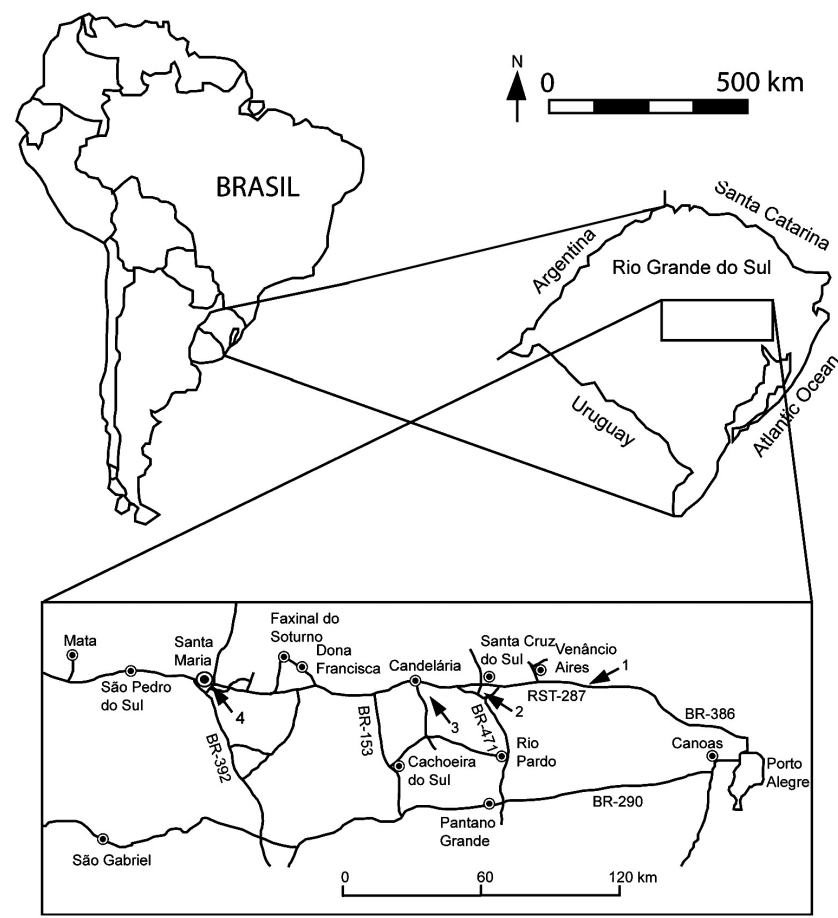

Figure 1. Map showing the geographic location (arrows) of the studied outcrops: 1, Vila Estância Nova; 2, Schoenstatt; 3, Sanga Pinheiros; 4, Faixa Nova.

Archosauromorpha) dominate the upper one. The chronostratigraphic datum for the Rhynchosaur Biozone is a radiometric age of $227 \mathrm{My}$. obtained at the basis of the Ischigualasto Formation from Argentina (Rogers et al., 1993), in which the same rhynchosaurs occur. Therapsid nonmammalian cynodonts occur both in Therapsid and Rhynchosaur Biozones, but are represented by distinct taxa in each one of them (Abdala et al., 2001).

The Traversodontid Biozone fills the hiatus between the Therapsida and Rhynchosauria Biozones, corresponding to the Neoladinian, as proposed by some authors (Scherer $e t$ al., 1995, Schultz et al., 1994, 2000; Figure 4).

\section{MATERIALS AND METHODS}

The material studied (Table 1) consists of bone fragments of cynodonts collected from the Schoenstatt and Vila Estância Nova outcrops, which belong to the collection of the Paleontology and Stratigraphy Department of the Universidade Federal do Rio Grande do Sul (UFRGS). In both outcrops the bones are disarticulated, sometimes fragmented or crushed, probably due to trampling. There is no evidence of selective transport, nor a preferential bone orientation, which confirms the absence of hydraulic influence on the distribution of the bones. All the bones occur in a pelitic matrix, which formed in a low-energy environment (Machado, 2004).

The materials collected in Schoenstatt and Vila Estância Nova outcrops are macroscopically very similar, with a thin and darkned layer covering all the bones. The absence of significant volumetric changes in the bones from these outcrops also becomes evident when compared to the 
Table 1. Listing of the materials used in this study. ${ }^{*}$ Thin plates prepared and used in previous work by Holz \& Schultz (1998).

\begin{tabular}{l|cc}
\hline CATALOG NUMBER & THIN PLATE & LOCALITY \\
\hline UFRGS PV0582T & M1 & Schoenstatt \\
UFRGS PV0582T & M2 & Schoenstatt \\
UFRGS PV0431T & M7 & Schoenstatt \\
UFRGS PV0578T & M11 & Schoenstatt \\
UFRGS PV0579T & & Schoenstatt \\
UFRGS PV0583T & M12 & Schoenstatt \\
UFRGS PV0582T & M13 & Schoenstatt \\
UFRGS PV0582T & M14 & Schoenstatt \\
UFRGS PV0458T & M5 & Vila Estância Nova and \\
UFRGS PV0582T & M3 & Schoenstatt \\
UFRGS PV0454T & M4 Estância Nova \\
UFRGS PV0457T & M8 & Vila Estância Nova \\
UFRGS PV0589T & Vila Estância Nova \\
UFRGS PV0454T & M10 & Vila Estância Nova \\
UFRGS PV0455T & $*$ & Vila Estância Nova \\
UFRGS PV0969T & $*$ & Sanga Pinheiros \\
UFRGS PV0970T & $*$ & Faixa Nova \\
UFRGS PV0298T & $*$ & Faixa Nova \\
\hline
\end{tabular}

materials from other localities of South Brazilian Triassic (e.g. those pictured by Holz \& Schultz, 1998 from Therapsid and Rhynchosaur Biozones).

In order to compare diagenetic patterns among different stratigraphic levels within the Santa Maria Formation, the fossils from Schoenstatt and Vila Estância Nova were confronted, with those coming from the Therapsid and Rhynchosaur Biozones (referred by Holz \& Schultz, 1998). Thin sections and respective fossil bones from dicynodonts (5 specimens) and rhynchosaurs (18 specimens) were used. From these, one specimen of dicynodont (thin section UFRGS PV0969T) and two of rhynchosaurs (thin sections UFRGS PV0970T and UFRGS PV0298T) were selected to be analyzed in detail. The thin section UFRGS PV0969T was analyzed by Scanning Electron Microscopy (SEM), as described below. The samples were separated into groups according to their origin: Vila Estância Nova, Schoenstatt, Sanga Pinheiros and Faixa Nova outcrops (Table 1).

An impregnation technique, adapted from Timm (1996), was applied to some bone samples in order to prepare them as thin sections for histological analysis under optical microscope (Figures 6 - 8). Another technique applied in this study was X-Ray diffractometry (XRD), using macerated materials. This technique characterizes the diagenetic processes that occurred at those paleoenvironments through the identification of the minerals present both in the bones and the surrounding matrix (Table 2). XRD analyses were performed with a Siemens D5000 diffractometer using Cu Ká radiation with generator conditions of $40 \mathrm{kV}, 20 \mathrm{~mA}$, with a step size of $0.02^{\circ} 2 \mathrm{q}$ and a time step of $1 \mathrm{~s}$.

Some of the sections were also analyzed by SEM. The samples selected were from Schoenstatt (M7), Vila Estância Nova (M9), and Sanga Pinheiros (one of thin sections used by Holz \& Schultz, in 1998, UFRGS PV0969T), representing the Therapsid Biozone. All these samples were coated with carbon. Qualitative and semi-quantitative chemical analyses

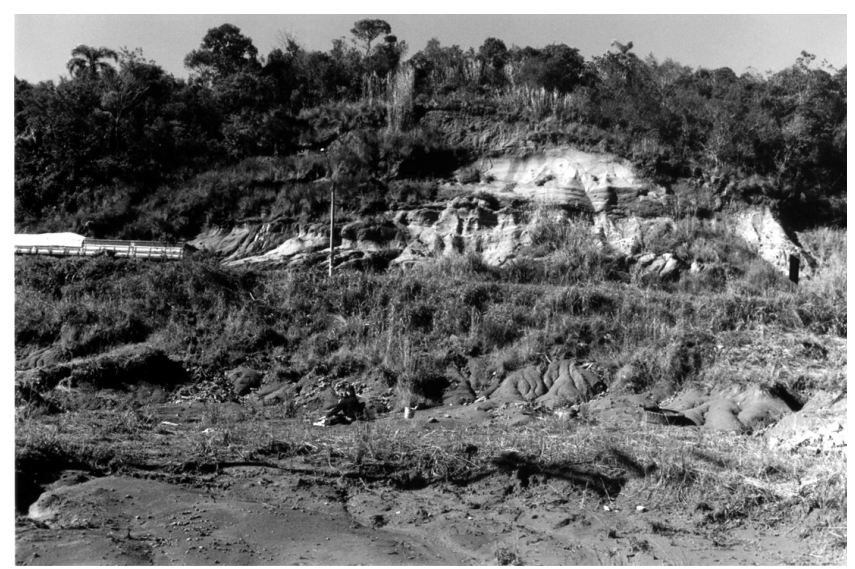

Figure 2. General view of the Schoenstatt outcrop (Santa Cruz do Sul).

with Electron Dispersion Spectroscopy (EDS) were made in selected spots in each sample (Figure 9). Each spot was photomicrographed (Figure 10).

\section{RESULTS}

\section{Optical microscopy}

Observation under an optical microscope indicated that all the bones collected in Shoenstatt and Vila Estância Nova have an equally poor histological preservation due to the dissolution of the bone tissue. This state of preservation precludes the identification of preserved bone structures, with the exception of some minor walls of the trabecular bone and also little fragments of lamellar bone (Figure 6). On the other hand, in most of the fossil bones from the Therapsid and Rhynchosaur Biozones (Holz \& Schultz, 1998) it is possible to observe more histological structures preserved (contrasting with the bad external preservation) such as almost complete bone lamellae (Figure 5). The main filling minerals in Schoenstatt and Vila Estância Nova outcrops are quartz (Figures 6 - 8), and calcite (Figure 8). The quartz crystals occur filling the pores of the bones, forming huge crystals or just aggregations of small crystals. In the thin sections from fossils from Therapsid and Rhynchosaur Biozones no quartz, but just calcite was found in the bones, between bone lamellae, splitting them (Figure 5). Calcite crystals are also present in the bones from Schoenstatt and Vila Estância Nova, but in much smaller quantity than in those from Therapsid and Rhynchosaur Biozones (Holz \& Schultz, 1998). In the thin sections, the dark layer which macroscopically characterizes the bones from Schoenstatt and Vila Estância Nova (Figures 6 and 8) occurs as well defined dark stains, not only covering the external border of the bones but also inside them, generally close to fractures.

\section{X-Ray Diffractometry (XRD)}

Three bone XRD analyses and two matrix XRD analyses were made on materials from Vila Estância Nova, while four bone analyses and one matrix analysis were made on Schoenstatt materials. The results of the analyses are presented in Table 2. In all bone samples fluorapatite was 


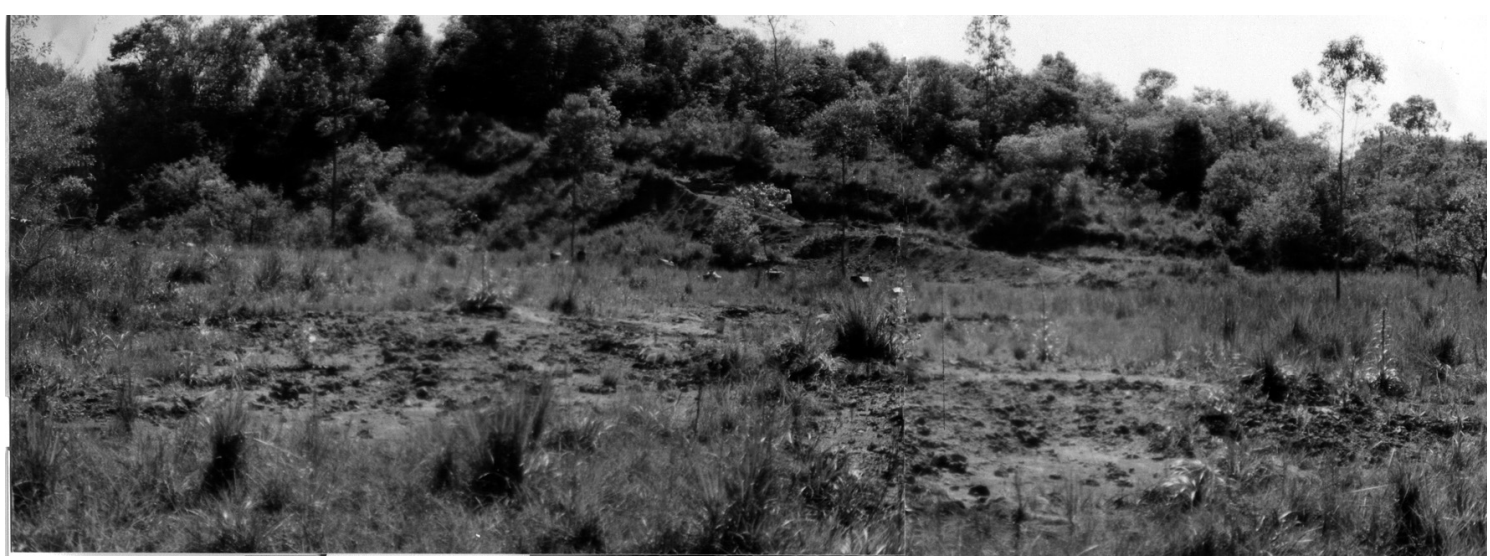

Figure 3. General view of the Vila Estância Nova outcrop (Venâncio Aires).

detected. Quartz and calcite are also detected in most bone samples, except for the sample UFRGS PV0579T (from Schoenstatt), where no calcite was detected and UFRGS PV0583T, where no quartz was detected. In all sediment samples quartz was detected.

\section{Scanning Electron Microscopy}

Figure 9 shows the percentages of $\mathrm{P}, \mathrm{Ca}$ and $\mathrm{Si}$ found in each sample. Three analyses were made on materials from the Therapsid Biozone collected in the Sanga Pinheiros outcrop (UFRGS PV0969T) and four on materials from the Traversodontid Biozone, two from the Schoenstatt (M7) and two from the Vila Estância Nova (M9) outcrops.

Three kinds of samplings are represented in Figure 9: those identified as "bone" represent EDS analyses of the elements detected in a bone spot. These samples present high concentration of $\mathrm{Ca}$ and $\mathrm{P}$ (reflecting just the presence of the main constituents of bone hydroxylapatite). The samplings identified as "pore" represent EDS analyses of pores of the bones, where diagenetic minerals were accumulated. The third kind of sampling, identified as "average", represents EDS analyses of spots containing both bone and pore fillings.

In one of the samples (M9) the dark layer, which covers the external surface of most bones, was also analyzed. An average percentage of $63.62 \%$ of $\mathrm{Mn}$ was detected, always associated with $\mathrm{Ba}$ (in concentrations of nearly 7\%). A photomicrograph of this $\mathrm{Mn}$ and $\mathrm{Ba}$ enriched area was taken (Figure 10). Low concentrations of $\mathrm{Al}$ (1.35\%), Si (3.54\%), Cl $(0.75 \%)$ and $\mathrm{Ca}(1.85 \%)$ were detected in the same sampling. On the other hand, in the fossils from Therapsid and Rhynchosaur Biozones, external layers around the bones are mainly represented by Fe oxides (Holz \& Schultz, 1998).

In some isolated samplings of Schoenstatt (M7) other elements were detected as $\operatorname{Ir}(0.96 \%), \mathrm{Nd}(19.94 \%)$ and V $(66.77 \%)$.

\section{DISCUSSION}

The study of the morphological and chemical characteristics of the fossil bones can provide information about environmental conditions during early taphonomic history. It is possible to determine the level of microstructure preservation of fossils only after microscopic analyses. All the microanalyses made here showed a poor histological preservation of the bones from Schoenstatt and Vila Estância Nova outcrops, on the contrary of the bones from Faixa Nova (Therapsid biozone) and Sanga Pinheiros (Rhynchosaur biozone) outcrops, in which the histological preservation is better in spite of the poor external preservation. The main permineralizing minerals in Schoenstatt and Vila Estância Nova outcrops are quartz and calcite and the external dark coloured layer is composed of $\mathrm{Mn}$ oxides and $\mathrm{Ba}$. Comparing these data to samples from Rhynchosaur and Therapsid biozones (Figure 9 - UFRGS PV0969T and observation of other thin sections under the optic microscope), where no quartz crystals are found, the high quartz $(\mathrm{Si})$ concentrations detected in Schoenstatt and Vila Estância Nova become even more evident, attributing them an exclusive mineralogic feature.

Quartz filling the pores of bones could result from pedogenic or phreatic processes in arid environments (Hesse, 1989). In the case of pedogenic processes, the quartz could result from the precipitation of inorganic silica in the form of silcretes, in a process closely related to soil formation and/or weathering (Hesse, 1989). Machado (2004) found some root marks in the Schoenstatt outcrop, which were interpreted as evidence of paleosoil. Regarding phreatic processes,

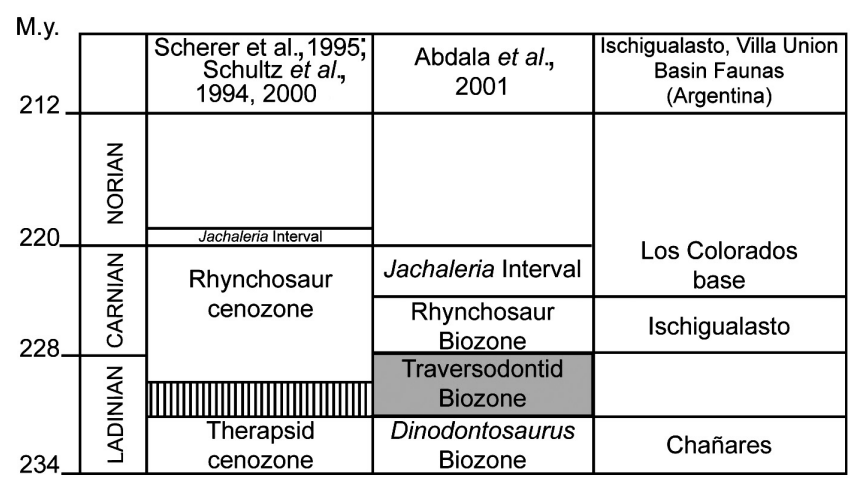

Figure 4. The zonation of Santa Maria Formation, indicating the hiatus cited in the text (striped area) and the new Traversodontid biozone (gray area) (modified from Abdala et al., 2001). 


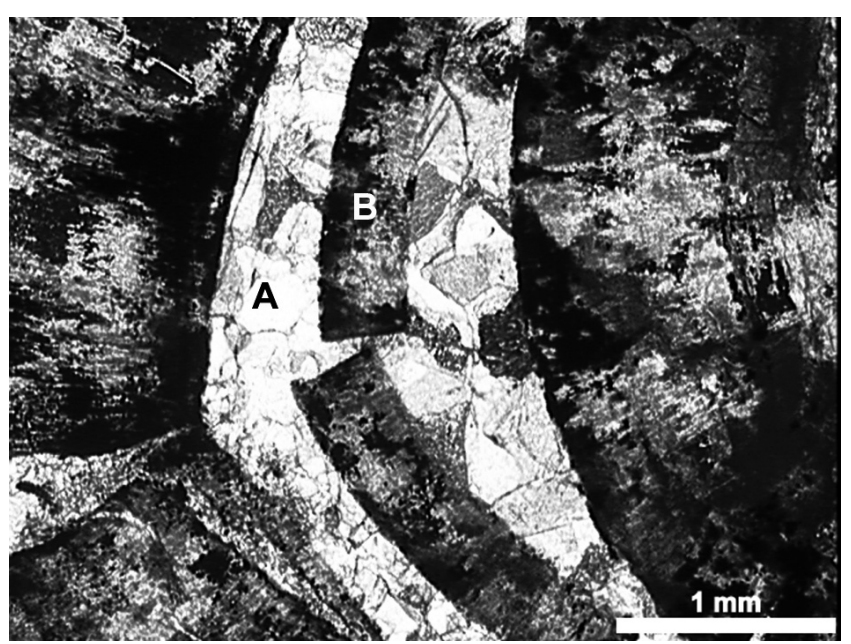

Figure 5. Photomicrograph of a bone from the Therapsid Biozone (Sanga Pinheiros outcrop): A, calcite crystals B, preserved bone lamellae.

silicification could occur in beds, resulting in heterogeneities in stratification. In both cases the bones act as a nucleus for the silicification when they are not in geochemical equilibrium with Si rich percolant fluids (if previously carbonated, for example). Therefore, they become potential targets for dissolution and epigenic substitution by quartz. The process could be incomplete (affecting just a percentage of the fossil, with some calcite remaining). So, it is possible that the silicification process in these fossils has been eodiagenetic over a previously carbonated material (also by phreatic or pedogenic processes, according to Da Rosa et al., 2003).

The exact mechanism of this switch between quartz/calcite deposition is still poorly understood. It is possible that changes in $\mathrm{pH}$ and silica concentrations may have caused dissolution of calcite and deposition of silica, or dissolution of silica and deposition of calcite (Krauskopf, 1972). Nevertheless, it is unclear what kind of environmental changes may have caused such geochemical alterations.

In the material studied low quartz concentrations are found in the bone samplings, demonstrating that this mineral concentrates preferentially in the pores, and not in the bone matrix itself (compare in Figure 9, bone and pore samples, from Schoenstatt [M7] and Vila Estância Nova [M9]). The quartz concentration in these samplings is much higher than that present in bones from Sanga Pinheiros (UFRGS PV0969T).

It is very important to stress that the absence of $\mathrm{Ca}$ in the pore of the Schoenstatt sample analyzed by SEM does not indicate the total absence of $\mathrm{Ca}$ in all pores, because the diagenetic minerals do not necessarily have a homogeneous distribution inside the fossils. In fact, the presence of calcite was detected for Schoenstatt and Vila Estância Nova fossils by X-Ray Diffractometry (Table 2) and Optic Microscopy analyses (Figure 8).

The Optic Microscopy analyses (Figures 5 - 8) enable us to visualize the real difference between the mineral filling of the bones from the Traversodontid biozone (Schoenstatt and Vila Estância Nova outcrops) and the bones from the other biozones. In the Schoenstatt and Vila Estância Nova outcrops,

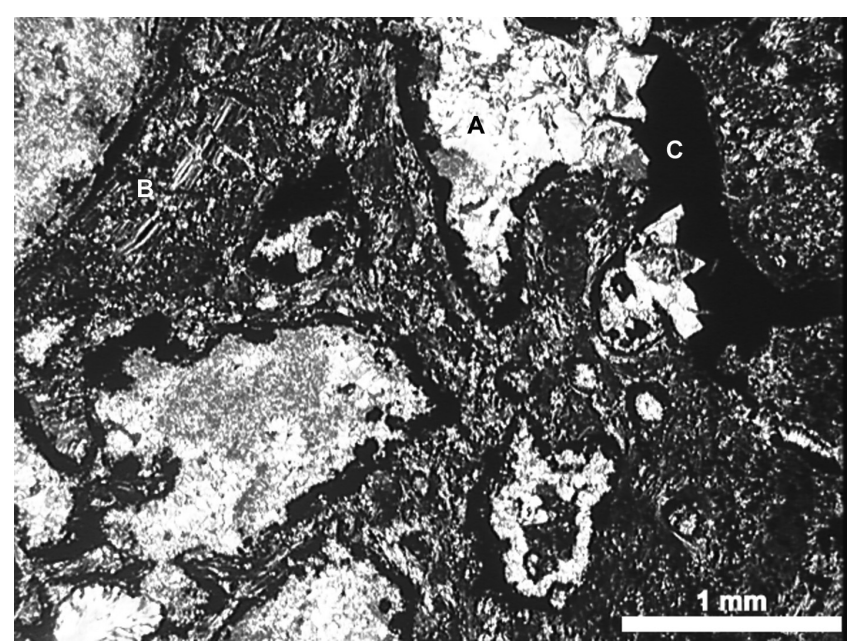

Figure 6. Photomicrograph of a bone from the Vila Estância Nova outcrop: A, quartz crystals, B, bone layers, C, manganese.

the quartz crystals are clear and easily recognizable, demonstrating a different diagenetic pattern between those outcrops and those where no quartz crystal was recognized (Holz \& Schultz, 1998).

These microscopic analyses demonstrate that there is no relationship between the appearance of the bones and their histological preservation. The same was concluded in a microscopical analysis of archaeological bones (Garland, 1989). This author stressed the intimate relationship between the depositional environment and the histological preservation of bone tissues. Therefore, the similar histological preservation pattern observed in Schoenstatt and Vila Estância Nova samples suggests a correlation between both the localities studied and their respective depositional environments. In both, the same kind of dissolution of bone tissue can be observed. Hard skeletal parts dissolution can occur during diagenesis or weathering due to the infiltration of water associated with $\mathrm{pH}$ variations of the environment. Calcite is dissolved in acid conditions,

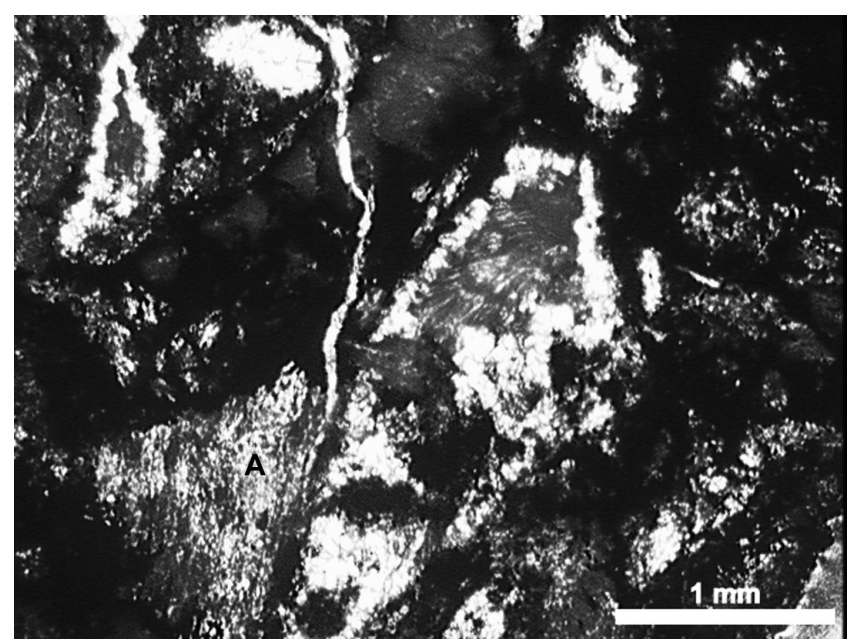

Figure 7. Photomicrograph of a bone from the Schoenstatt outcrop: A, Quartz crystals. 


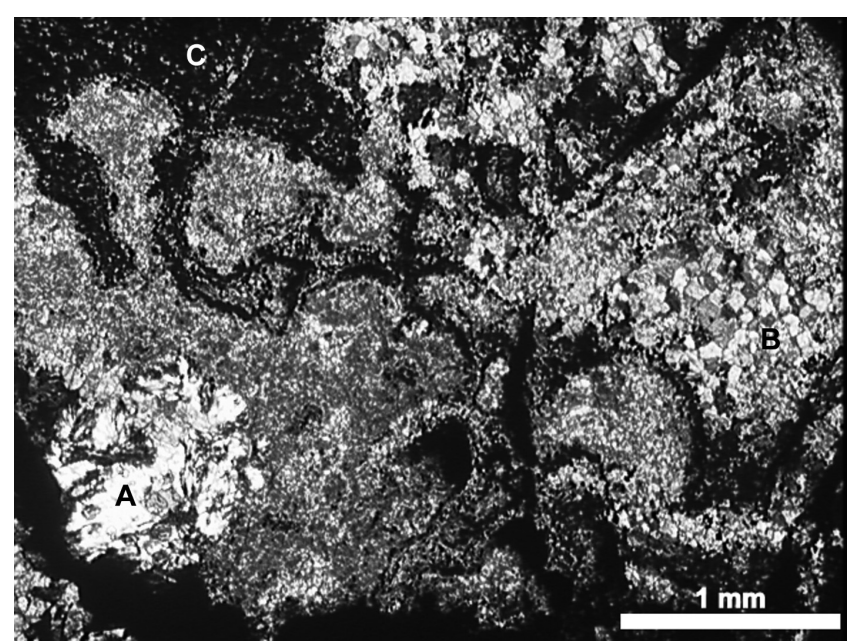

Figure 8. Photomicrograph of a bone from the Vila Estância Nova outcrop: A, quartz crystals, B, calcite crystals, C, manganese.

while quartz becomes soluble under alkaline conditions (Holz $\&$ Simões, 2002). Therefore, the sedimentary environment at the time of the Traversodontid Biozone may have been more acidic during the beginning of the fossilization process (eodiagenesis), allowing the precipitation of quartz in the pores of the bones.

Geochemical considerations indicate that the silica released during weathering of alkali feldspars will not be used up completely by the formation of clay minerals, because in the most abundant clay minerals, $\mathrm{Si}$ :Al ratios are below 2:1 whereas in alkali feldspars ratios are $3: 1$. During alteration of alkali feldspars to clay minerals, silica is left over and from this excess silica quartz can be formed. The solubility of amorphous silica in water at $25^{\circ} \mathrm{C}$ and at a $\mathrm{pH}$ below 9 is about $120 \mathrm{ppm} \mathrm{SiO}_{2}$, with silica in solution in the monomeric form. It has been shown that even from strongly undersaturated solutions (concentrations down to $0.5 \mathrm{ppm}$ $\mathrm{SiO}_{2}$ ) silica can be adsorbed by hydroxides of Fe, $\mathrm{Al}, \mathrm{Mn}, \mathrm{Mg}$ and other elements. So, in natural sedimentary environments, the hydroxides of $\mathrm{Fe}, \mathrm{Al}, \mathrm{Mn}, \mathrm{Mg}$, etc. adsorb silica and thus enable the formation of quartz in marine and fresh water environments (Harder \& Flehming, 1970). At this point it is important to stress the presence of manganese in the fossils analyzed, which may have some influence in the quartz concentration on the outcrops studied.

The formation of silicic acid $\left(\mathrm{H}_{4} \mathrm{SiO}_{4}\right)$ in shallow waters or in the interstitial waters, or in the interstitial water of a quartzous sediment (Taguchi et al., 1988), is probably related to intense rainfall during early diagenetic stages. This would lead to a minor acidification around fossil bones, which could cause damage to the bone structure. However, when this silicic acid encounters an alkaline environment, represented by a previously carbonated bone, precipitation of silica in the bone pores begins. This could explain why the fossil bones from these outcrops present a poor histological preservation but keep their original size, preventing the volumetric changes which occur in the bones coming from the other biozones (like those studied by Holz \& Schultz in
Scanning Electron Microscopy (SEM) results

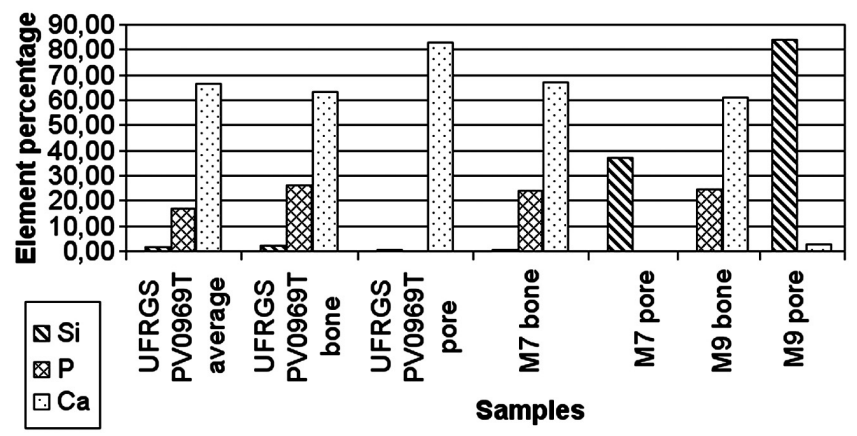

Figure 9. Percentage of $\mathrm{Si}, \mathrm{P}$ and $\mathrm{Ca}$ detected in the samples, with SEM.

1998) caused by the expansive growing of calcite crystals inside the bones. The silicification of fossils, as an eodiagenetic process, turns them relatively resistant to any other subsequent diagenetic processes (Carson, 1991), as compression or physical distortions.

The apatite detected in the fossils was identified as fluorapatite by the XRD, so that the fossil-bone mineral is francolite (carbonate fluorapatite), rich in fluorine and carbon dioxide. According to Newesely (1989), in vivo bones begin a crystalographic maturation of the hydroxylapatite with an incorporation of $\mathrm{F}^{-}$to its structure in very low concentrations. This substitution may continue during diagenesis, depending on the conditions of the environment. Dahllite (the apatite with $\mathrm{F}^{-}$concentration $<1 \%$ ), which occurs in in vivo bones, changes to francolite (the apatite with $\mathrm{F}^{-}$concentration $>1 \%$, which was detected by the XRD analyzes). The fluorine does not only substitute the hydroxyls $\left(\mathrm{OH}^{-}\right.$radicals in hydroxylapatites), which can completely disappear, but also substitutes $\mathrm{PO}_{4}^{3-}$ for $\mathrm{CO}_{3}{ }^{2-}$, while the apatite turns into carbonate-fluorapatite (Lucas \& Prévôt, 1991). These chemical alterations occur by simple ionic change. The increase in fluorine concentration during

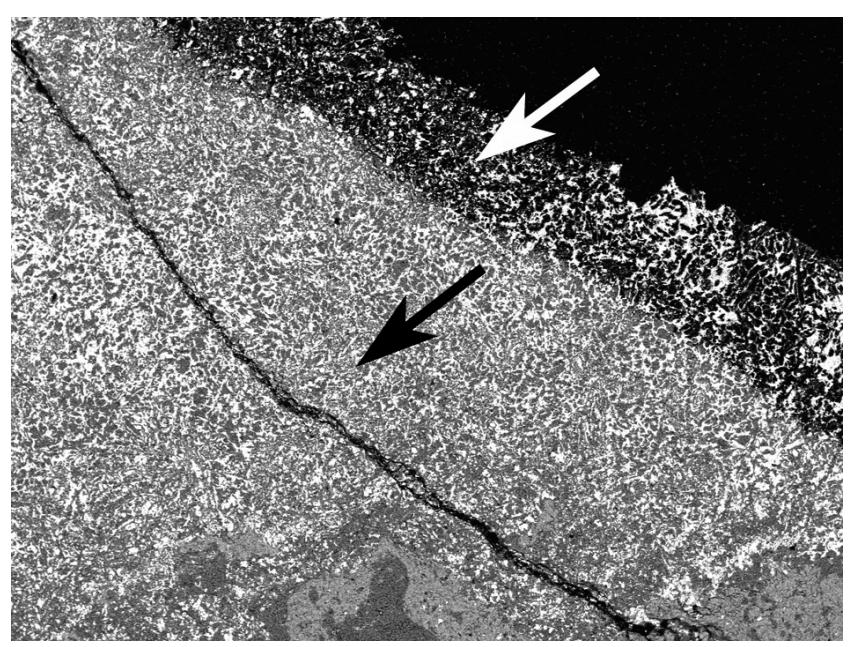

Figure 10. Photomicrograph of a bone area (black arrow) covered with a manganese layer (white arrow). 80X amplification. 
Table 2. Minerals detected in the XRD analyses.

\begin{tabular}{c|ccc}
\hline SAMPLE MATERIAL & SAMPLE NUMBER & DETECTED MINERALS & LOCALITY \\
\hline Bone & UFRGS PV0589T & quartz, barite, calcite, fluorapatite & Vila Estância Nova \\
Bone & UFRGS PV0589T & quartz, calcite, fluorapatite & Vila Estância Nova \\
Bone & UFRGS PV0457T & quartz, calcite, fluorapatite & Vila Estância Nova \\
Sediment & SEDVENA & quartz, calcite, albite, montmorilonite, barite & Vila Estância Nova \\
Sediment & Venâncio-Sediment & smectite, quartz, alcaline feldspate, & Vila Estância Nova \\
Bone & plagioclasium & Schoenstatt \\
Bone & STACOS PV0579T & fluorapatite, quartz, lime, montmorilonite & Schoenstatt \\
Bone & fluorapatite, quartz, lime, halosite, & Schoenstatt \\
Bone & UFRGS PV0582T & montmontmorilonite & Schoenstatt \\
Sediment & UFRGS PV0583T & barite, calcite, fluorapatite & Schoenstatt \\
\hline
\end{tabular}

diagenesis can lead to a higher crystallinity (Lucas \& Prévôt, 1991), as also observed in a study about diagenesis in Superior Cretaceous fossils, in which a higher crystallinity in bones was documented (and its original apatite was substituted by francolite), when compared to modern bones (Elorza et al., 1999).

The hydroxylapatite is relatively insoluble in high $\mathrm{pH}$ soils, but localized acidity around the skeleton, as those described above, could increase its solubility (as well as its propensity to suffer any kind of damage). The nature of the ionic substitutions between the bone apatite and the surrounding sediment can also influence the solubility of the hydroxylapatite: substitutions involving fluorines decrease its solubility, while carbonatic inclusions increase it (Pate et al.,1989).

In the Schoenstatt and Vila Estância Nova outcrops, the ionic changes between the sediment and the bones studied led to the substitutions of $\mathrm{OH}^{-}$by $\mathrm{F}^{-}$(see Table 2, the detection of fluorapatite [francolite] by the XRD). Therefore, the reduction of the apatite solubility could have contributed to a better morphological preservation of the bones (in spite of poorer histological preservation). The fossils of the Therapsid and Rhynchosaur Biozones, which were affected by carbonate solutions, present marked volumetric changes (Holz \& Schultz, 1998).

Nevertheless, the most important factor for the preservation of these fossils has not only been the occurrence of silica, but the occurrence of silica associated with other factors. The processes that involve the precipitation of silica inside the bone pores indicate acid environments, which could damage the bones if they were exposed for a too long time to such conditions (because the bones could have been completely dissolved). The presence of calcite increased the alkalinity, preventing these excessive acid conditions.

In this case, even if hydroxylapatite represents the best defined constituent of the inorganic matrix of the bone, it does not occur in a pure state, nor represents the only inorganic phase (Newesely, 1989). This indicates that diagenesis is not a simple process and never depends on one isolated factor or mineral. Not just the soil and groundwater, but the bone itself has a complex and variable inorganic composition that contributes to variations of the diagenetic processes. Therefore, strong similarity between the diagenetic patterns of different localities can be very useful for stratigraphic correlation.

Many details can still be explored in the future, including the trace elements detected by SEM analyses (Mn, Ba, V, Nd, Ir) and their paleoenvironmental implications, leading to a more precise understanding of the relationship between the outcrops studied and an understanding of the biology of the collected fossil groups (Williams, 1989; Williams et al., 1997; Toots \& Voorhies, 1965).

\section{CONCLUSIONS}

The outcrops of Schoenstatt (Santa Cruz do Sul) and Vila Estância Nova (Venâncio Aires) present the same diagenetic pattern, which is distinct from others within the Santa Maria Formation. Both of them present a high percentage of silica filling the bones, while in the other levels (Therapsid and Rhynchosaur Biozones), silica is absent. It could be observed both in optic microscopy and SEM analyzes. A distinct biostratinomic pattern was also observed for the fossil assemblages of these outcrops (Machado, 2004). These diagenetic and biostratinomic patterns, which are shared by Schoenstatt and Vila Estância Nova outcrops and differ from those of the other biozones, reinforce the existence of a distinct biozone for the middle portion of the Santa Maria Formation, even if represented by two isolated outcrops.

The faunal change, observed in the Traversodontid Biozone, could be interpreted in this case, as a consequence of an environmental change (arid climate, according to Machado, 2004), which would produce the distinct sedimentary facies observed in this unit within the Santa Maria Formation.

\section{ACKNOWLEDGMENTS}

We would like to thank Marina B. Soares for all the assistance and helpful references. Additional thanks to Átila da Rosa, Michael Holz and Cristina B. Machado for the comments on early version and for collecting materials. 
Cristina B. Machado kindly provided us with the figures 2 and 3. We also are grateful to Renato F. da Silva, for the XRD analyses and to João F. da Rosa for the thin sections. CNPq provided financial support.

\section{REFERENCES}

Abdala, F. \& Ribeiro, A.M. 2000. A new therioherpetid cynodont from the Santa Maria Formation (middle Late Triassic), southern Brazil. Geodiversitas, 22(4):589-596.

Abdala, F.; Ribeiro, A.M., \& Schultz, C.L. 2001. A rich cynodont fauna of Santa Cruz do Sul, Santa Maria Formation (MiddleLate Triassic), Southern Brazil. Neues Jahrbuch für Geologie und Paläontologie Monatshefte, 2001:669-687.

Abdala, F. \& Ribeiro, A. M. 2003. A new traversodontid cynodont from the Santa Maria Formation (Ladinian-Carnian) of southern Brazil, with a phylogenetic analysis of Gondwanan traversodontids. Zoological Journal of the Linnean Society, 139:529-545.

Carson, G.A. 1991. Silicification of fossils. In: P.A. Allison \& E.G. Briggs (ed.) Taphonomy, Releasing the Data Locked in the Fossil Record, Plenum Press, p. 456-499.

Chinsamy, A. 1997. Assessing the biology of fossil vertebrates through bone histology. Palaeontologia Africana, 33: 29-35.

Da Rosa, A.S.; Faccini, U.F. \& Pimentel, N.L. V. 2003. Dinâmica sedimentar versus litoestratigrafia: em busca de critérios alternativos de identificação de sequiências sedimentares triássicas da porção central do Rio Grande do Sul, Sul do Brasil. In: I ENCONTRO SOBRE A ESTRATIGRAFIA DO RIO GRANDE DO SUL: ESCUDO E BACIAS, 1, 2003. Anais:escudo e bacias, Porto Alegre, UFRGS, p. 164-169.

Elorza, J.; Astibia, H.; Murelaga, X. \& Pereda-Suberbiola, X. 1999. Francolite as a diagenetic mineral in dinosaur and other Upper Cretaceous reptile bones (Laño, Iberian Peninsula): microstructural, petrological and geochemical features. Cretaceous Research, 20:169-187.

Garland, A.N. 1989. Microscopical analysis of fossil bone. Applied Geochemistry, 4:215-229.

Hesse, R. 1989. Silica diagenesis: origin of inorganic and replacement cherts. Earth-Science Reviews, 26:253-284.

Harder, H. \& Flehming, W. 1970. Quarzsynthese bei tiefen temperaturen. Geochimica et Cosmochimica Acta, 34(3):295-300.

Holz, M. \& Barberena, M.C. 1989. A importância da tafonomia para o Estudo de Vertebrados Fósseis. Acta Geologica Leopoldensia, 29:77-92.

Holz, M. \& Schultz, C.L. 1998. Taphonomy of the South Brazilian Triassic herpetofauna: fossilization mode and implicartions for morphological studies. Lethaia, 31:335-345.

Holz, M. \& Simões, M.G. 2002. Elementos Fundamentais de Tafonomia. $1^{\text {a }}$ ed. Porto Alegre. Editora da Universidade/ UFRGS, $231 \mathrm{p}$.

Krauskopf, K.B. 1972. Introdução à geoquímica V.1. São Paulo. Polígono, Editora da USP, 294 p.

Lucas, J. \& Prévôt, L.E. 1991. Phosphates and fossil preservation. In: P.A. Allison \& E.G. Briggs (ed.) Taphonomy, Releasing the Data Locked in the Fossil Record. Plenum Press, p. 389-409.
Lucas, S.G. 2001. Age and correlation of Triassic tetrapod assemblages from Brazil. Albertiana, 26:13-20.

Machado, C.B. \& Kischlat, E.E. 2003. Novo registro de Rhadinosuchidae (Archosaurimorphes: Proterochampsia) para o Mesotriassico do Brasil. Paleontologia em Destaque, 44:47.

Machado, C.B. 2004. Concentrações fossilíferas controladas pelo nível freático: um modelo tafonômico para reconstruções paleoambientais. Programa de Pós-Graduação em Geociências, Universidade Federal do Rio Grande do Sul, Dissertação de Mestrado, $73 \mathrm{p}$.

Newesely, H. 1989. Fossil bone apatite. Applied Geochemistry, 4:233-245.

Pate, F.D.; Hutton, J. T. \& Norrish, K. 1989. Ionic exchange between soil solution and bone: toward a predictive model. Applied Geochemistry, 4:303-316.

Rogers, R.R.; Swisher III, C. C.; Sereno, P.C.; Monetta, A.M.; Forster, C.A. \& Martinez, R.N. 1993. The Ischigualasto tetrapod assemblage (Late Triassic, Argentina) and ${ }^{40} \mathrm{Ar} /{ }^{39} \mathrm{Ar}$ dating of dinosaur origins. Science, 260:794-797.

Scherer, C.M.; Faccini, U.F.; Barberena, M.C.; Schultz, C.L. \& Lavina, E.L. 1995. Bioestratigrafia da Formação Santa Maria: utilização das cenozonas como horizontes de correlação. Comunicações do Museu de Ciências e Tecnologia UBEA/PUCRS, série Ciências da Terra, 1:43-50.

Scherer, C.M.S.; Faccini, U.F. \& Lavina, E.L. 2000. Arcabouço estratigráfico do Mesozóico da Bacia do Paraná. In: M. Holz \& F. De Ros (eds.) Geologia do Rio Grande do Sul. Editora UFRGS, p. 335-354.

Schultz, C.L.; Holz, M. \& Gamermann, N. 1990. Tafonomia de vertebrados Permo-Triássicos: a diagênese como fator de alteração morfológica. Ciência e Natura, 12:77-81.

Schultz, C.L.; Scherer, C.M.S. \& Barberena, M.C. 1994. Uma nova proposta de zoneamento estratigráfico para o Triássico Superior sul-rio-grandense. In: CONGRESSO SUL-BRASILEIRO DE GEOLOGIA, 38, 1994. Boletim de Resumos, Camboriú, UNISC, p. 107-108.

Schultz, C.L.; Scherer, C.M.S. \& Barberena, M.C. 2000. Bioestratigraphy of Southern Brazilian Middle-Upper Triassic. Revista Brasileira de Geociências, 30(3):491-494.

Taguchi, K.; Hasegawa, K. \& Suzuki, T. 1988. The relationship between silica minerals and organic matter diagenesis: Its implication for the origin of oil. Organic Geochemistry, 13(13):97-108.

Timm, L.L. 1996. Estudo paleo-histológico acerca da paquiostose em mesossauros. Programa de Pós-Graduação em Geociências, Universidade Federal do Rio Grande do Sul, Dissertação de Mestrado, $182 \mathrm{p}$.

Toots, H. \& Voorhies, M.R. 1965. Strontium in fossil bones and the reconstruction of food chains. Science, 149:854-855.

Williams, C.T. 1989. Trace elements in fossil bone. Applied Geochemistry, 4:247-248.

Williams, C.T.; Henderson, P.; Marlow, C.A. \& Molleston, T.I. 1997. The environment of deposition indicated by the distribution of rare earth elements in fossil bones from Olduvai Gorge, Tanzania. Applied Geochemistry, 12:537-547.

Received November, 2004; accepted June, 2005. 